\title{
Morphological analysis of legal ideology: locating interpretive divergence
}

Article

Accepted Version

Lees, E. and Shepherd, E. (2018) Morphological analysis of legal ideology: locating interpretive divergence. Journal of Property, Planning and Environmental Law, 10 (1). pp. 5-16. ISSN 2514-9407 doi: https://doi.org/10.1108/JPPEL-12-20170041 Available at https://centaur.reading.ac.uk/75250/

It is advisable to refer to the publisher's version if you intend to cite from the work. See Guidance on citing.

To link to this article DOI: http://dx.doi.org/10.1108/JPPEL-12-2017-0041

Publisher: Emerald

All outputs in CentAUR are protected by Intellectual Property Rights law, including copyright law. Copyright and IPR is retained by the creators or other copyright holders. Terms and conditions for use of this material are defined in the End User Agreement.

\section{www.reading.ac.uk/centaur}

\section{CentAUR}

Central Archive at the University of Reading

Reading's research outputs online 


\section{Introduction}

This paper outlines a methodology for locating and explaining disagreement among the judiciary as to the proper interpretation of legal norms, particularly in a politicised and administratively flexible context such as UK environmental or planning law. In so-doing, it explores the role of ideology in law, theorised as a ubiquitous form of political thinking and a part of the broader concept of legal culture, and how ideology can shape and mould judicial decision-making in a hitherto underexplored way. The discussion focuses on rule of law as but one form of legal ideology. Given word constraint, we envisage this article in the form of a 'manifesto' which seeks to open potential avenues of research and stimulate debate on the methodologies employed in relation to the analysis of environmental and planning law. We see this as appropriate in the context of the re-launch of this journal.

We do not, of course, suggest that all disagreement in the interpretation of legal norms can be explained by ideology. Some, unquestionably, relate to different understandings of deference and the role of the courts as but one decision-making organ within the wider democratic state. Other disagreements can be put down to divergent understandings of the context surrounding any particular legal problem; the purpose of the relevant legislative measure; or the wider goals within the legal system concerning, for example, human rights protection or environmental protection. However, we suggest that there is an important contribution to be made by considering the role of ideology in legal decision-making and the contestation this entails, and that, particularly in highly politicised contexts, some nuance may be missing from our existing analyses by failing to draw out this aspect of judicial reasoning (McAuslan, 1980).

This relatively modest methodological claim is, however, potentially controversial in that it depends upon a number of more or less acceptable jurisprudential concepts, not least thanks to the fact that the mere idea that the practice of law is itself in some sense ideological is anathema to those who seek to ensure judicial neutrality. Thus, we explain, that the forms of ideology which we seek to analyse are not traditional political ideologies in the sense of 'liberal', 'socialist', 'conservative' etc., but rather ideologies specifically internal to legal practice. The form of such internal legal ideology which we discuss here is that of rule of law (Fuller, 1964).

From the outset we acknowledge two challenges for this approach. First, the meaning of rule of law as ideology may be as much contested as all forms of ideology (that, we argue, is actually the point), but it does mean that in order to identify contestation under the umbrella of rule of law as a political and legal ideal we have to make certain initial choices as to what range of meanings we may safely label in this way. In making these choices we have tried to accommodate a range of views in accepting that rule of law is made up of concepts including but not necessarily limited to certainty, equality, stability, and legality (Bingham (2010, p. 38), Raz (1979, p. 211), Fuller (1969, 
chapter 2) - for a thorough history of the various approaches taken to the term through history, see (Tamanaha, 2004). In essence we adopt a 'formal' approach to rule of law, (see Craig, 1997).

Second, we acknowledge that as a practical task, it may be near impossible to disaggregate the influence of ideology on judicial decisions from the influence of other factors, including but not limited to linguistic or purposive approaches to interpretation. Nevertheless, as the exercise conducted in Annex 1 shows, focusing on attempting to find ideological influence within decisions does produce interesting results. Thus, we argue that notwithstanding these challenges, an understanding of how ideology may shape judicial decision-making can contribute towards a rich and nuanced picture of the role of contestation in structuring the legal framework and public political institutions. The analysis is less concerned with attempting to isolate the role of ideology so as to establish causation, than it is concerned with mapping and identifying the range of ideological contestations surrounding legal concepts so as to interpret the possible range of disagreement over their meanings, and how these meanings may be politically 'fixed' (albeit temporarily) in individual decisions.

In order to achieve this, we first explain our conception of ideology and how it can shape political decision-making in general. Following (Freeden, 1998, 2013a, 2013b), we theorise ideologies as comprising morphologies of essentially contested concepts, with different ideologies seeking to fix the meanings of these concepts in competing ways in order to exert control over the terms by which the political is understood. We then demonstrate how such an approach can be translated into the study of law (Part I). Second, we examine the concept of legal culture, and show how legal ideology is a specifically political element ${ }^{1}$ of wider legal culture, thus contextualising our methodological approach within the broader on-going debates surrounding the importance of legal culture to legal outcomes (Part II). Third, we explain how rule of law can be understood as an ideologically essentially contested legal concept which itself comprises specific legal concepts which are also contested, so that different forms of political thinking about rule of law entail different interpretations of its component concepts with potentially significant implications for how the rule of law is applied in legal decisions (Part III). We then conclude by explaining how this theory can be tested within a legal system, and what such an examination may reveal (Part IV).

\section{I: Ideology and the Morphological Approach}

This paper proposes a theory for the study of how the influence of latent (though not, we suggest, necessarily illegitimate) attitudes, values and beliefs of the judiciary may be traced in legal doctrine. To do so, it suggests that the concept of ideology in law can be honed in to an analytical tool which can be used to locate and explain disagreement among the judiciary as to the proper interpretation of legal concepts. The approach taken is closely based on Freeden's influential 'morphological' approach for the study of political ideologies (Freeden, 1998, 2013a).

\footnotetext{
${ }^{1}$ We use the term 'element' here but recognise that this risks oversimplifying the nature of the relationship between the two concepts. However, it does suggest that legal ideology may be conceived of as being encompassed by the broader concept of legal culture which is for the time being sufficient for our analytical perspective for the purposes of this paper.
} 
Following Freeden, the concept of ideology employed in this paper is therefore broadly sociological. Ideology is understood as a form of group political thinking common to all. It is not, therefore, a specifically pejorative conception of ideology. Ideology as political thinking may obfuscate, distort and legitimise powerful interests (Engels \& Marx, 1998), but this is not a necessary condition for ideology. As a 'ubiquitous and permanent form of political thinking' (Freeden 2013a, p.116), thinking ideologically is something in which we all engage in an attempt to impose seemingly determinate meaning on an indeterminate political world. The study of ideology and ideologies, therefore, becomes the study of this collective political meaning-making.

However, if ideology is so ubiquitous as to be the very stuff of political thought and action, then how is one to identify and study it? This is the problem which is created by adopting a sociological conception of ideology rather than a pejorative one. Shorn of its explicitly critical dimension, ideology risks becoming a near synonym for 'culture', defined by anthropologist Geertz $(1973$, p.5) as the 'webs of significance' spun by humankind in which it is itself suspended. It thus risks becoming merely a descriptive lens, rather than an analytical tool. However, Geertz's significant contribution to ideology studies was his insight that ideologies can be conceived of as cultural systems which function 'to make an autonomous politics possible by providing the authoritative concepts that render it meaningful, the suasive images by means of which it can be sensibly grasped' (Geertz 1973b, 218).

This idea that ideologies in some sense comprise concepts is the cornerstone of Freeden's morphological approach to the study of political ideologies. Freeden (1998) takes forward Geertz's semiotic emphasis and combines it with W.B.Gallie's philosophy (1955-56) to suggest that political ideologies can be theorised as comprising morphologies of 'essentially contested concepts'. For Freeden, ideologies act to control the limits of interpretation of these concepts (to 'decontest' them) so as to seek to exert control over the terms by which political reality is understood. Ideologies may therefore be analysed in terms of which essentially contested concepts they are concerned with, what those concepts are taken to mean, and how they relate to each other. Thus, rule of law as a form of legal ideology, for example, may be analysed in terms of the contested concepts which make it up: certainty, equality, stability, legality, and so on.

Crucially, according to such a morphological approach, the concepts comprising an ideology could mean subtly different things and relate to each other differently in different contexts and in different times (to use the example of liberalism - does 'liberty' mean 'freedom from constraint', or 'freedom to self-develop within a community', and what is the relation with the concept of 'property' in each of these conceptions?). There are therefore many different liberalisms, just as there are many 'rules of law', although they all have a Wittgensteinian 'family resemblance' which arises from a shared emphasis on concepts which are fundamental to the ideology (it is hard to imagine a 'liberalism' which does not have some kind of concept of 'liberty' at its core; similarly, no conception of rule of law survives without the concept of 'legality'). 
Freeden's contribution to the study of political ideologies is that he presents us with an approach which is relatively systematic. The study of political ideologies becomes a case of identifying and mapping their morphological structures using the language of political theory and political philosophy. Crucially, this also allows for the systematic analysis of changes in ideologies over time and across different geographical contexts, and for the systematic analysis of how individual concepts are decontested by different ideologies. It is the comparative rigour of the approach which means that it can be adapted to help us analyse the presence of ideology within the legal framework.

\section{II: Translating Ideological Analysis into Legal Method}

Following Cotterrall (2006, p.90), we argue that the analysis of legal ideology presents a 'more manageable theoretical task' than the analysis of legal culture, because the analysis of legal ideology explores 'mechanisms by which law...exerts influence on, or translates and thereby helps reinforce, wider structures of values, beliefs and understandings' with 'professionally managed legal doctrine...taken as its specific focus, rather than a potentially unlimited diversity of cultural sources of influence on legal systems'. To this we would add that the concept of ideology is explicitly concerned with the political. This is to say that to think ideologically is to think politically.

To 'think politically' is here understood in a broad sense; it is to think in a way which is concerned with 'the drive to finalize collective affairs through decisions' (Freeden 2013b, p.22). Therefore, thinking politically may involve obviously political thinking about how decisions should be made regarding wealth allocation for example, but it also involves thinking about how decisions should be made regarding the interpretation of policies relating to the supply of housing, or regarding liability for the polluter under the polluter pays principle. These are collective problems, decisions about which entail closing off alternative responses which could arise from alternative conceptions of the problem and the range of potential solutions. Therefore the study of the influence of ideology on the legal doctrine becomes the study of how contested legal concepts are interpreted and institutionalised in the decisions comprising the legal framework, which may be to the benefit or dis-benefit of certain group interests. If ideology is a specifically political element of a wider cultural system of meaning, then it offers a more bounded purview of analysis than 'legal culture'.

However, Freeden's approach to the study of political ideologies was developed for the study of the great ideological families such as liberalism, socialism and conservatism. It therefore needs to be adapted so as to be suitable for the analysis of legal doctrine. Legal doctrine is not, itself, an ideology - it does not propose a more or less coherent and ostensibly comprehensive group political vision of how society and the economy should be structured, along with a programme of action for implementing this vision. However, following discursive institutional theory, legal doctrine can be conceived of as comprising political ideas and concepts which have become institutionalised and therefore form part of a legal framework guiding human thought and action (Béland and Cox 2011; Blyth 2002; Schmidt 2010). 
The analysis of legal ideology as manifested in legal doctrine therefore becomes a case of identifying these contested concepts and analysing how they have been interpreted by the courts to produce particular political outcomes. Freeden's morphological approach for the study of political ideologies requires an analysis of the meaning and articulation of the concepts they comprise. We can therefore adapt this approach to develop an analysis of how certain concepts have been decontested in legal doctrine with the primary sources being the decisions of the courts.

We therefore need to further adapt Freeden's morphological approach to assist with the analysis of individual contested concepts within the legal doctrine by acknowledging their fractal qualities. That is to say, individual concepts can be analysed in terms of their own morphological arrangements. For example, a legal concept such as rule of law can be the concern of a broader political ideology such as 'liberalism' and may have a limited range of meanings within the morphology of that ideology. Yet as a concept it too comprises an arrangement of concepts which limit its range of meanings. These concepts may be 'thinner' than the single concept of which they are part, yet they are still open to contestation in terms of their meanings, relationships and the different weight attached to them.

As explained above, the concept of rule of law could be analysed as comprising the concepts of certainty, equality, stability, and legality etc. Different decision-makers may have different understandings of these concepts and award them different weight in decision making, thereby resulting in different interpretations both of the concept of the rule of law in different legal decisions and of the norm being scrutinised in an instant case. The analysis of ideology within the legal framework therefore becomes a case of identifying contested concepts, and conducting a morphological analysis of how they have been decontested in different legal decisions and then drawing conclusions regarding the implications for the coherence and justiciability (or otherwise) of the resultant legal framework.

In this way, the systematic qualities of Freeden's approach may be incorporated into the analysis of the legal doctrine in order to draw out the precise terms of disagreement among the judiciary as to the proper interpretation of legal concepts. The competing 'webs of political meaning' comprising different legal ideologies may therefore be analysed and their effects on the legal framework and its implications for certain interest groups may be understood. As with the related concept of 'legal culture', this means that the analysis of 'legal ideology' lends itself to comparative analyses. The morphological approach may be employed to conduct comparisons of the decontestations of contested concepts in different legal doctrines, and across the same legal doctrine over time.

\section{Ideology as distinct from but part of legal culture}

Given the current scholarly focus on the importance of acknowledging and understanding legal cultures (Scotford: 2017; Warnock and Pedersen: 2017), especially when engaged in a comparative study (Lees: forthcoming 2018), it is useful here to explore more deeply how the concept of ideology relates to the wider concept of legal culture. Many scholars have highlighted the importance of understanding and analysing legal culture in explaining how legal rules are utilised in 
any particular legal system. This notion of legal culture has come particularly to the fore in recent years in highly politicised contexts, especially environmental law, where the idea of legal culture is used to explain, among other things, how and why environmental principles are treated differently in different courts, despite apparently the same justifications, normative underpinnings, and ostensible role. However, we only consider one aspect of legal culture, that is, the ideology of the institution of the judiciary within a legal system.

Before moving on to explain the method that we propose for 'spotting' this element of 'legal culture', especially in a politicised context (in our case, that of planning law and decision-making), it is important to understand what we mean by that concept. Nelken has explained that, '[1]egal culture, in its most general sense, is one way of describing relatively stable patterns of legally oriented social behaviour and attitudes' (Nelken: 2004 - emphasis added). A key element of this definition is the contingency of legal culture - it is only relatively stable, and therefore contingent and open to adjustment. However, this 'general' meaning does not fully capture the importance of culture to our argument. Rather, we are looking at one aspect of this definition, that is, 'more nebulous aspects of ideas, values, aspirations and mentalities. Like culture itself, legal culture is about who we are not just what we do' (Nelken: 2004).

We are seeking, in short, to explore how the judiciary perceive, from an internal perspective, what the ideas, values, aspirations and mentalities are, which motivate their own decision-making, separate from the particularised content of the rule which they apply. Their understanding of values etc. will of course shift depending upon the particular context, both legal and practical, within that rule being applied: this is what we mean by the contingency of legal culture. Nevertheless, the judge's attitude to 'who she is' qua judge and her understandings of the concepts which comprise the webs of significance shaping her understanding of her role and her deliberations will affect the decision that she reaches when interpreting or applying legal norms.

In examining this, we take what Nelken calls an interpretive approach. We do not claim to be able to prove causation, but rather claim that understanding the role of ideology as a form of political thinking in legal culture can help us to understand and interpret the process of judicial decisionmaking. Thus, '[t]he mainstream social science explanatory approach to legal culture typically seeks to assign causal priority between competing hypothetical variables. The interpretative approach, on the other hand, is more concerned to understand how aspects of legal culture resonate and fit together. It sees its task as faithfully translating another system's ideas of fairness and justice and making proper sense of its web of meanings' (Nelken: 2004). We aim to 'faithfully translate' the judicial attitude to their own role, and to use this as part of the 'web' of multiplicity of considerations which influence the result in any particular dispute.

This interpretive approach is particularly important to the wider project in which we employ ideology in law as a methodological tool for developing a rich understanding of how planning decisions are handled by the courts. The relevance of the interpretive approach to our project can be seen here: 'scholars who adopt the interpretative approach contrast the different meanings of the 'Rule of Law', the 'Rechtstaat', or the 'Stato di diritto' etc (Nelken: 2004). This explanation of how legal culture can be used as a comparative exercise gives a clear indication as to how understanding legal culture, and, as we shall explain, ideology as an element of that, can be useful 
in exploring what happens within a legal system. We therefore examine different meanings and understandings of rule of law within a particular system, as expressed through the internal ideology of the judiciary as a group.

In suggesting this, however, we recognise the risks of considering legal culture. As Nelken highlights, '[g]iven that culture is, to a large extent, a matter of struggle and disagreement, the purported uniformity, coherence or stability of given national cultures will often be no more than a rhetorical claim projected by outside observers or manipulated by elements within the culture concerned. Much that goes under the name of culture is no more - but also no less - than 'imagined communities' or 'invented traditions', though these may of course be real in their effects' (Nelken 2004). We strive, as far as possible, to avoid these traps, and indeed, it is because of this very struggle and disagreement (or 'contestation') that we see ideology as being such an important part of legal culture since, as defined here, ideologies seek to fix the range of meanings of essentially contested concepts and thus impose stability and coherence upon an indeterminate and contingent cultural world. This is what it means to think and act politically: '[The] need for semantic control...is at the heart of the political' (Freeden 2013b, p.6). Indeed the language of politics 'is shot through with the vocabulary of finality'; yet this 'quest for finality and decisiveness in the affairs of groups... are permanently frustrated by the slippery and inconclusive circumstances in which that quest occurs' (Freeden 2013b, p.22). Thus we acknowledge and indeed exploit the fact that culture comprises meanings which are by definition not uniform, coherent or stable, and that ideology as political thinking is specifically concerned with imposing a sense of stability through 'the decision', which is 'the fundamental thought-practice of finality' (Freeden 2013b, p.22).

\section{III: 'Rule of Law' as Ideology}

We now move to consider rule of law as one part of this ideological, legal culture picture. It is our contention that rule of law itself constitutes an ideological perspective (as above defined, see also Waldron, 2002). To substantiate this claim, we suggest that 'rule of law' as an ideal is a concept which may be analysed by reference to other, contested concepts, such as certainty, equality, stability, and legality. Furthermore, we argue, in line with the prevailing scholarly tradition, that rule of law, as an ideal, is one which is complied with more or less, rather than as a binary yes or no, but that most individuals would characterise the nature of the scale, and the placement of any particular legal system on that scale, differently. Thus, as Moroni argues in the context of the compliance of planning law systems with the rule of law ideal: '[t]he rule of law is then a substantive meta-legal ideal regarding what we should consider a "good" law' (Moroni, 2007, p.148), but ' $[\mathrm{t}]$ he ideal of the rule of law is, clearly, a guiding ideal; in other words, conformity to the rule of law will often be a matter of degree' (Moroni, 2007, p.148).

It is useful here also to clarify that rule of law is not necessarily contrary to discretion in law, and as such, discretionary administrative decision-making does not run counter to rule of law values. Rather, certain types of discretion do so run counter. This is an important clarification for it gives some insight into why, in the planning and environmental context, judicial discussions of the role of administrative discretion in such decision-making is sometimes although not always an analysis attempting to ensure compliance with some conception of rule of law. Thus, as Moroni states: 
'the term 'discretion' has many possible meanings. And only one is relevant from the point of view of defenders of the rule of law ideal. Here it is useful to again quote Hayek (1960/1999: 213): "Under the rule of law the private citizen and his property are not an object of administration by government . . . It is only when the administration interferes with the private sphere of the citizen that the problem of discretion becomes relevant"...Therefore a system based on the rule of law can accept some kinds of discretion, but not any kind of discretion' (Moroni, 2007, p.152).

\section{Rule of Law and English and Welsh Planning Law}

It has been argued cogently that the English and Welsh planning law system, relying as it does on highly individualised decision-making by local authorities with discretion bounded only be the requirements that all 'material considerations' be taken into account in reaching a decision (subject to the twin presumptions in favour of both the local development plan and the NPPF via the definition of 'sustainable development). This highly discretionary process has been the subject of much litigation, with a large amount of judicial ink spilt on the question of how 'deferential' or otherwise a court ought to be in respect of the exercise of such discretion. Thus, per Tewdwr-Jones (1999: 247 - as quoted in Moroni, 2007) 'spatial planning in Britain has operated as a discretionary, flexible activity, and the concept of a rule of law is alien to how the system has been implemented over the last 50 years'. Needham agrees with this assessment, arguing that 'British statutory town and country planning does not meet the requirements of the rule of law, for the decision whether or not an action will be prohibited is not predictable in advance, being open to the discretion of the state administration' (p. 148). However, as we have argued elsewhere, this failure to comply with rule of law is not merely a result of a highly discretionary system. In many respects, it is an inevitable consequence of the establishment of a series of inconsistent rules, resulting in decisionmakers being 'obliged to reconcile the irreconcilable' (Lees and Shepherd 2015). We noted, in reaching this conclusion, that:

'Planning policy is broadly drafted, especially at a national level, and individual decision-makers are relied upon to reach sensible and practical decisions which achieve 'reasonable' outcomes. In such a context perhaps an underlying lack of commitment to understandings of core concepts, or as to the appropriate balance of power within a state, could be said not to matter. They do matter however, and they matter because once policy is brought down to an individual decision, in almost all cases a prioritisation must be made - localism, or sustainable development; autonomy or prescription, and this prioritisation is made by local planning authorities, planning inspectors and the courts. In sodoing, they must interpret the terms of policy and legislation. They must fix the meanings of ambiguous concepts, in so doing prioritising one of the competing ideologies enshrined in planning policy, and they must allocate power of decision-making to one authority over another'. (Lees \& Shepherd 2015, p.122)

In 'fixing' these competing political ideologies, however, the judiciary inevitably engages the ideology of its own internal perspective, that is to say the ideology of 'rule of law'. By 'internal' ideology here, we are referencing the idea developed by Hart amongst others, that one can identify a legal system according to the internal 'rules of the game' by which is meant those norms by which actors within the system see themselves as bound. In taking such an approach, we must reject an interpretivist theory of the legal system which looks only to practice, but we argue that it is in the practice of the judiciary that we can see the effect of implicit, or half-hidden internal norms.

\section{IV: Spotting Ideology within Judicial Decision-making}


It is in this context of planning decision-making, problematic as it may be in 'rule of law terms' that our methodology can be demonstrated however. Thus, we suggest that it is possible and helpful to consider judicial decisions in relation to planning, and explore how the courts treat the key concepts of, in particular, certainty, equality, stability, and legality (whether of their own initiative, or, for example, parasitic upon the Equality Act) to explore how each judge's understanding of rule of law values might be shaping their approach to the interpretive question before them. Space does not permit a detailed demonstration of this methodology at work, but nevertheless a short example is useful in demonstrating how the theoretical discussion surrounding the role of ideology in law and legal culture can be translated into a practical step for exploring the influence of these ideas.

Thus, in a series of decisions concerned with the question of the meaning of 'policies for the supply of housing' in paragraph 49 of the National Planning Policy Framework for England (relevant since any local policy for the supply of housing should not be considered up-to-date in the making of a planning decision where a local planning authority cannot demonstrate a five year supply of deliverable housing $\operatorname{sites}^{2}$ ), the courts have reached a series of divergent conclusions as to this meaning. In some cases the courts put this down to merely differing linguistic considerations; in others the divergence is expressed in terms of differing attitudes to judicial deference. However, it is also notable that in all of these decisions, the judges make reference to certainty and clarity in particular, marshalling these concepts as justifications for the interpretive approach they have taken. The critical point however is not that these courts are using these ideas to justify the outcome they reach, but that it is clear on close inspection that the courts have subtly different interpretations (or 'decontestations') as to what these concepts mean and, in part, this contributes to conflicting or at least inconsistent decisions on this question.

This can be seen even on a simple comparison between the various judgments in the Hopkins Homes Ltd $v$ Secretary of State for Communities and Local Government saga concerning this question of the meaning of 'policies for the supply of housing'. The Court of Appeal had adopted a wide interpretation of this phrase, including within it policies such as infrastructure and transport strategies which would inevitably have had a clear impact on housing supply. The Supreme Court took a more narrow approach, holding that polices for the supply of housing were limited to those which directly targeted housing. In the process of reasoning, the various judges (first instance, Lindblom LJ in the Court of Appeal and Lords Carnwath and Gill in the Supreme Court) utilised concepts of certainty and predictability in different ways, leading them, or at least partly leading them, to differing conclusions.

To put this another way, in all of the judgments in both courts it is clear that each judge was keen to ensure that his or her solution to the interpretive question would ensure certainty, clarity and accessibility in the application of the rules so that, broadly speaking, the rules were easily and clearly understood and applied by policy-makers, lay-persons and courts alike. That this was a concern of the court is unsurprising - 'rule of law' is, as we have argued, the guiding internal principle which motivates the court - but on closer inspection it becomes apparent that they have

\footnotetext{
${ }^{2}$ This is reduced to a requirement for the local planning authority to demonstrate a three year supply of deliverable housing sites where the application site lies within an adopted neighbourhood plan area and certain other conditions are met as set out in a written ministerial statement of 12 December 2016 (Barwell, 2016).
} 
different kinds of certainty in mind when invoking these concepts as a way to legitimise the decision reached (this exercise is carried out in Annex 1). We suggest that a deeper understanding of the resulting decisions and judicial disagreements can be gained from exploring this.

We acknowledge, however, that ideology as a factor shaping judicial decisions is itself, dependent upon the nature of that decision and the multiplicity of other factors which will weigh on the courts' shoulders when reaching conclusions of this kind. Exactly how and where any particular ideology becomes relevant within a judicial decision is contingent upon the nature of the rule itself, the wider context within which it operates, and the precise nature of the dispute at hand. Thus, we do not suggest that theorising that the judiciary is just as ideological as all other political institutions will help to predict the eventual outcome of a case per se. However, we do posit that understanding ideology and its role in decision-making provides a useful insight into the wider institutional question of how legal culture affects rules, rule-making, and application of those rules by the judiciary and we suggest a methodology by which this influence can be traced.

\section{Conclusions}

In this 'manifesto' paper, we have reached four critical conclusions. First, ideology can be understood as a ubiquitous form of political thinking which seeks to fix the meanings of essentially contested concepts and whose influence on the legal framework can therefore be systematically analysed by considering variations in how such concepts are interpreted in various legal contexts. Second, ideology in this sense forms an important part of, but is distinguishable from, the wider notion of legal culture. Considering ideology separately from consideration of legal culture can therefore be helpful in providing a rich understanding of interpretive disagreements. Third, rule of law as an ideal is itself ideological in the sense above, being made up of contested concepts such as equality, accessibility, certainty and stability. It can be considered to constitute the internal ideology of law. Finally, understanding this can help in the analysis of judgments in areas of high levels of administrative discretion, such as planning and environmental law, as it helps us to understand how any particular judge sees the role of the court in its wider political context. 


\section{References}

- Barwell, G. (2016) Neighbourhood planning: written statement HCWS346, available at https://www.parliament.uk/business/publications/written-questions-answers-statements/writtenstatement/Commons/2016-12-12/HCWS346/, accessed 30 January 2018.

- Béland, D. \& Cox, R.H. (eds) (2011) Ideas and Politics in Social Science. Oxford, Oxford University Press.

- Bingham, T. (2010) The Rule of Law, Allen Lane, Harmondsworth.

- Blyth, M. (2002) “Institutions and Ideas”. In: D. Marsh, \& G. Stoker (eds). Theory and Methods in Political Science. Houndmills and New York, Palgrave McMillan. pp. 292-310.

- Cotterrall, R. (2006) Law, Culture and Society: Legal Ideas in the Mirror of Social Theory. Aldershot, Ashgate.

- Craig, P. (1997) "Formal and Substantive Conceptions of the Rule of Law" Public Law 467 at p. 467.

- Engels, F. \& Marx, K. (1998) The German Ideology: Including Theses on Feuerbach and Introduction to the Critique of Political Economy. Prometheus Books, Amherst, NY.

- Freeden, M. (1998) Ideologies and Political Theory: A Conceptual Approach [ebook] Oxford University Press, Oxford, available at http://www.oxfordscholarship.com/view/10.1093/019829414X.001.0001/acprof9780198294146?rskey=849G9T\&re sult=1, accessed 7 December 2017.

- Freeden, M. (2013a). “The Morphological Analysis of Ideology”. In: M. Freeden, L.T. Sargeant, \& M.S. Strears (eds). The Oxford handbook of political ideologies, Oxford, Oxford University Press. pp. 115 - 134.

- Freeden, M. (2013b) The Political Theory of Political Thinking: The Anatomy of a Practice, Oxford, Oxford University Press.

- Friedman, F. (1994) “Is there a Modem Legal Culture?” Ratio Juris, vol. 7, p.117.

- Fuller, L. (1964) The Morality of Law, Yale University Press, New Haven. -- (1978) “The Forms and Limits of Adjudication” Harvard Law Review, vol. 92, p.353.

- Gallie, W.B. (1955-56). "Essentially Contested Concepts" Proceedings of the Aristotelian Society, New Series. 56 (1955-56), p.167.

- Gardner, J. (2008) "Law and Morality", available at https://papers.ssrn.com/sol3/papers.cfm?abstract_id=2344794. A later version of this paper appeared as, “Ethics and Law” in Skorupski, J (ed), (2010) The Routledge Companion to Ethics, Routledge, London.

- Geertz, C. (1973a) “Thick Description: Towards an Interpretive Theory of Culture”. In: C. Geertz. The Interpretation of Cultures: Selected Essays. Basic Books: New York. pp.3-30.

- Geertz, C. (1973b) “Ideology as a Cultural System”. In: C. Geertz. The Interpretation of Cultures: Selected Essays. Basic Books: New York. pp.193-232.

- Hayek, F. A. (1973) "Rules and Order" in Law, Legislation and Liberty University of Chicago Press, Chicago pp. 72 ff.

- Lees and Shepherd. (2015) "Incoherence and incompatibility in planning law" International Journal of Law in the Built Environment, vol. 7. pp. 111-126.

- Moroni, S. (2007) "Planning, Liberty and the Rule of Law” Planning Theory vol. 6, p. 146.

- McAuslan, P. (1980), The Ideologies of Planning Law, Pergamon, London.

- Nelken, D. (2004) "Using the Concept of Legal Culture” 29 Australian Journal of Legal Philosophy. vol. 29, p 26 
- Raz, J. (1979) The Authority of Law, Clarendon Press, Oxford.

- Schmidt, V.A. (2010) "Taking ideas and discourse seriously: explaining change through discursive institutionalism as the fourth "new institutionalism"” European Political Science Review, vol. 2, p.1.

- Sypnowich, C. (2001, updated 2014) "Law and Ideology" available at https://plato.stanford.edu/entries/lawideology/, accessed 22 December 2017).

- Tamanaha, B. (2004) On the Rule of Law: History, Politics, Theory, Cambridge University Press, Cambridge.

- Tewdwr-Jones, M. (1999) “Discretion, Flexibility, and Certainty in British Planning”, Journal of Planning Education and Research vol. 18, p. 244.

- Raz, J. (1979) “The Rule of Law and Its Virtue," in The Authority of Law, Clarendon Press, Oxford

- Waldron, J. (2002) "Is the rule of law an essentially contested concept (in Florida)" Law and Philosophy, vol. 21, p 137

-- (2012) The Rule of Law and the Measure of Property Cambridge University Press, Cambridge 


\section{Annex 1}

\begin{tabular}{|c|c|}
\hline Quotation & Meaning of certainty \\
\hline $\begin{array}{l}\text { 'There is nothing in the statute which enables the } \\
\text { Secretary of State to create such a fiction' [21] (Lord } \\
\text { Carnwath) }\end{array}$ & Certainty in the sense of compliance with published rules. \\
\hline $\begin{array}{l}\text { 'It must be exercised consistently with, and not so as to } \\
\text { displace or distort, the statutory scheme' [21] (Lord } \\
\text { Carnwath) }\end{array}$ & Clarity in the form of coherence across the legal system. \\
\hline $\begin{array}{l}\text { 'However, some concerns were expressed by the } \\
\text { experienced counsel before us about the over-legalisation } \\
\text { of the planning process, as illustrated by the proliferation } \\
\text { of case law on paragraph } 49 \text { itself (see paras } 27 \mathrm{ff} \text { below). } \\
\text { This is particularly unfortunate for what was intended as a } \\
\text { simplification of national policy guidance, designed for } \\
\text { the lay-reader. Some further comment from this court may } \\
\text { therefore be appropriate' [23] (Lord Carnwath) }\end{array}$ & $\begin{array}{l}\text { "Over-legalisation" contrasted with "simplification" for } \\
\text { the "lay-reader" - certainty and accessibility of the law. }\end{array}$ \\
\hline $\begin{array}{l}\text { 'All counsel who have appeared before us echo that view, } \\
\text { and urge us to bring much needed clarity to the meaning } \\
\text { of the policy. The benefit of this for local planning } \\
\text { authorities, developers and local communities will be } \\
\text { obvious' [2] (Lindblom LJ) }\end{array}$ & $\begin{array}{l}\text { "Clarity" - i.e. a determinate rule which is easily applied, } \\
\text { whether or not it actually produces a predictable (in the } \\
\text { sense of in line with purpose) result. }\end{array}$ \\
\hline $\begin{array}{l}\text { 'the only interpretation consistent with the obvious } \\
\text { purpose of the policy when read in its context' [32] } \\
\text { (Lindblom LJ) }\end{array}$ & $\begin{array}{l}\text { "Moral certainty" - i.e. the certainty which can be found } \\
\text { in the interpretation which gives the best effect to the } \\
\text { purpose behind the rule. }\end{array}$ \\
\hline $\begin{array}{l}\text { "This may be regarded as adopting the "narrow" meaning, } \\
\text { contrary to the conclusion of the Court of Appeal. } \\
\text { However, this should not be seen as leading, as the lower } \\
\text { courts seem to have thought, to the need for a legalistic } \\
\text { exercise to decide whether individual policies do or do not } \\
\text { come within the expression' [59] (Lord Carnwath) }\end{array}$ & $\begin{array}{l}\text { 'Common sense certainty' - the certainty that is to be } \\
\text { found in not over-complicating a legal issue }\end{array}$ \\
\hline $\begin{array}{l}\text { 'To some extent the issue in these cases has been obscured } \\
\text { by the doctrinal controversy which has preoccupied the } \\
\text { courts hitherto between the narrow and the wider } \\
\text { interpretation of the words "relevant policies for the } \\
\text { supply of housing". I think that the controversy results } \\
\text { from too narrow a focus on the wording of that paragraph' } \\
\text { [81] (Lord Gill) }\end{array}$ & $\begin{array}{l}\text { Contrast this with the approach to certainty expressed by } \\
\text { Lord Carnwath above. }\end{array}$ \\
\hline $\begin{array}{l}\text { 'the process of simplification has in certain instances led } \\
\text { to a diminution in clarity' [4] (Sir David Keene) }\end{array}$ & $\begin{array}{l}\text { Contrast this with the approach to certainty expressed by } \\
\text { Lord Carnwath above. }\end{array}$ \\
\hline
\end{tabular}


